\title{
Synthesis and Characterizations of Dinuclear Dioxomolybdenum(VI) Complexes with Thiocarbohydrazides of Salicylaldehyde, Bridged by 4,4'-Dipyridyl or Its Derivatives
}

\author{
Bon Kweon Koo, Haesung Kang, and Woo Taik Lim \\ Deparment of Chemistry, Cathohc Lniversity of Daegu, Gyeongsan, Gyeongbuk 712-702, Korea. "E-mail: bkkooaku.ac.kr \\ ${ }^{\dagger}$ Department of Applied Chemistry, Andong National Lniversitv, Andong, Gleongbuk 760-7+9, Korea \\ Recerved June 3, 2008
}

Key Words : Dinuclear molỵbdenum(VI) complexes. trans-1.2-Bis(+-pỵridỵl)ethỵlene. Schiff-Bașe ligands. Crystal structure

Molybdenum chemistry has received intense attention because of its biochenical role in metalloenzymes and its rich chemistry. It is well-known that molybdenum as a constituent of enzymes participates in redox reactions. e.g. oxidation of sulfide, aldehydes, xanthine and other purines. and reduction of nitrate to molecular nitrogen. ${ }^{2}$ In the oxidized forms of certain molybdoenzymes. the presence of the $c / s$-dioxonolybdenum(VI) cation, $\left[\mathrm{MoO}_{-}^{-]^{-}}\right.$has stimulated both the search for new structures in which this moiety is coordinated to ligands containing nitrogen. oxygen and/or sulfur donors and also the study of their chemical. spectroscopic. electrochenical and structural properties. ${ }^{3.7}$

Tridentate ONS-chelating schiff base ligands derived from thiosenicarbazide or dithiocarbazate of salicylaldehyde have been widely used in much of this work. ${ }^{\text {s.11 }}$ The tautomerism (Scheme 1) of these ligands as well as the well known tendency of sulfur donors to act as bridging ligands allows various structural possibilities for the corresponding metal complexes.

As part of our studies on the coordination chemistry of dblock metal complexes with schiff base ligands, we have earlier reported the synthesis and spectroscopic and electrochemical properties for the dioxomolybdenum(VI) complexes. such as $\left[\mathrm{MoO}_{2} \mathrm{~L}(\mathrm{MeOH})\right][\mathrm{L}=$ salicylaldehyde $\mathrm{N}$. phenylthiosemicarbazate (sal-phtsc ${ }^{2-}$ ) or salicylaldelyde $\mathrm{S}$ methyldithiocarbazate (sal-mdtc $\left.\left.{ }^{2-}\right)\right]$ and $\left[\mathrm{Mo}_{2} \mathrm{O}_{4} \mathrm{~L}=\right](\mathrm{L}=$ salicylaldehyde 2 -amino-4-t-butylphenol). ${ }^{12,13}$ The oxomolybdenum complexes with dibasic tridentate schiff bases are of the type: monomeric-[MoO $(\mathrm{L})(\mathrm{S})](\mathrm{L}=$ schiff base, $\mathrm{S}=$ monodentate neutral ligand), which is dominant. or dimeric$[\mathrm{MoO}(\mu-\mathrm{O})(\mathrm{L})]_{2}$ with asymmetric double oxygen bridge. or polymeric with single oxygen bridge ${ }^{14}$ However, the linear dianine/diimine-bridged dinuclear oxomolybdenum(VI) complexes are not very familiar and not adequately explor-

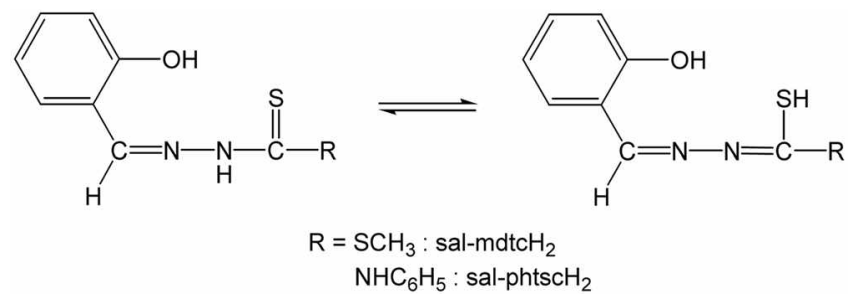

Scheme 1. The tautomerism of schiff base ligands. ed. ${ }^{15}$ In this paper, we report the synthesis and crystal structure on some new dimeric dioxomolybdenum(VI) complexes containing schiff base and 4.4'-bipyridyne (4.4'-bpy). trans-1.2-bis(4-pyridyl)ethylene (4.4'-bpe). or 4.4'-dipyridyldioxide (4.4'-dpdo) ligands which is directional and can be established multinuclear compound.

\section{Experimental Section}

All the reagents and solvents employed were commercial and used without further purification. The schiff bases. salmdtc $\mathrm{H}_{2}$ and sal-phts $\mathrm{CH}_{2}$, were prepared by the literature methods. $^{16}$

C. H. N. for the complexes were analyzed by using a Carlo-Erba EA-1106R. The IR spectra of solid samples in ATR method were recorded on a JASCO FT-IR 4100 type A. The ${ }^{1} \mathrm{H}-\mathrm{NMR}$ spectra in DMSO- $d_{6}$ were recorded on a Varian AS $400 \mathrm{MHz}$ spectrometer and referenced to TMS (intenal). Electronic spectra were obtained on a Milton Roy Genesys 2 UV/Vis. spectrophotometer. Themogravimetric (TG) and differential themal analysis (DTA) were perfonmed on a Shimadzu DTG-60 instrument with a heating rate of $10^{\circ} \mathrm{C} \cdot \mathrm{min}^{-1}$

$\left[\mathrm{Mo}_{2} \mathrm{O}_{4}\left(\mathbf{s a l}-\mathrm{miltc}_{2}\left(t, t^{\prime}-\right.\right.\right.$-bpe)] (1). The reaction mixture of $\mathrm{MoO}_{2}(\mathrm{acac})_{2}(0.68 \mathrm{mmol}, 0.223 \mathrm{~g})$ and sal-mdtcH $\mathrm{H}_{2}(0.68$ mmol, $0.153 \mathrm{~g})$ in dichloromethane $(15 \mathrm{~mL}$ ) solution was refluxed for $2 \mathrm{~h}$ and to the solution was added 4.4'-bpe (0.34 mmol. $0.062 \mathrm{~g}$ ). The mixture was further refluxed for another $1 \mathrm{~h}$. The precipitate was filtered and the filtrate was left in room temperature for several days. The reddish crystalline was collected by suction filtration, washed with diethyl ether, and dried in vacuum oven. Yield: $57 \%(0.172$ g) based on Mo. Anal. Calcd. for $\mathrm{C}_{301} \mathrm{H}_{26} \mathrm{~N}_{6} \mathrm{O}_{6} \mathrm{~S}_{4} \mathrm{Mo}_{2}$ : $\mathrm{C}$. $40.64 ;$ H. $2.96 ;$ N. 9.48; S. 14.47. Found: C. $40.75 ;$ H, 3.03 : N, 9.43: S. 14.67. UV-Vis (DMF) [ $\left.\hat{\lambda}_{\max } \mathrm{nm}(\log \varepsilon)\right]: 400$ (3.98), $367(4.23), 352(4.26), 313(4.54), 301(4.63), 265$ (4.62), 259 (4.34), $253(4.30), 229(4.13), 220(4.22), 208$ (4.17). Significant IR bands $\left(\mathrm{cm}^{-1}\right)$ : 3062 (w). 1609 (m), 1600 (s), 1551 (s). 1492 (n), 1424 (w). 1273 (n). 1013 (w). $980(\mathrm{~m}), 926$ (s). $890(\mathrm{vs}), 885(\mathrm{~s}), 830(\mathrm{~m}) .75 \mathrm{l}(\mathrm{m}) .{ }^{1} \mathrm{H}$ NMR (400 MHz. DMSO-d $): \delta 2.56\left(\mathrm{~s}, \mathrm{~S}-\mathrm{CH}_{3}, 6 \mathrm{H}\right) .6 .92$ (d, ArH, $2 \mathrm{H}, J=8.4 \mathrm{~Hz}$ ). $7.04(\mathrm{t}, \mathrm{ArH} .2 \mathrm{H} . J=7.4 \mathrm{~Hz}), 7.5 \mathrm{l}(\mathrm{s}$, -NCH=CHN-, 2H), 7.55 (t, ArH, 2H), 7.57 (d, -NCHCH-, 
$4 \mathrm{H}) .7 .74$ (d. $2 \mathrm{H} . J=7.7 \mathrm{~Hz}$ ). 8.57 (d. $-\mathrm{NCHCH}-4 \mathrm{H}, J=4.8$ $\mathrm{Hz}$ ), 8.92 (s. $\mathrm{N}=\mathrm{CH}, 2 \mathrm{H}$ ). The reddish crystals, $\left[\mathrm{Mo}_{2} \mathrm{O}_{4}(\mathbf{s a l}-\right.$ mdtc) $)_{2}\left(\mathbf{4}, 4^{\prime}\right.$-bpe)] $\left(\mathrm{CH}_{3} \mathrm{OH}\right)$ (2). suitable for X-ray diffraction were obtained by slow diffusion of methyl alcohol into a dichloromethane solution. Yield: $15 \%(0.046 \mathrm{~g})$. Anal. Calcd. for $\mathrm{C}_{31} \mathrm{H}_{3 \mathrm{i}} \mathrm{N}_{6} \mathrm{O}_{7} \mathrm{~S}_{4} \mathrm{Mo}_{2}$ : C. 40.53: H. 3.29; N. 9.15; S. 13.96 . Found: C. 39.96; H. 3.21: N, 9.18; S. 13.85.

$\left[\mathrm{Mo}_{2} \mathrm{O}_{4} \text { (sal-mdtc }\right)_{2}\left(4, t^{\prime}-\right.$-bpy)] (3). The compound was prepared similarly by the method described above for the preparation of 1 , with use of $4,4^{\prime}$-bpy instead of 4.4'-bpe. Yield: $65 \%(0.190 \mathrm{~g})$. Anal. Calcd for $\mathrm{C}_{28} \mathrm{H}_{2} 4 \mathrm{~N}_{6} \mathrm{O}_{6} \mathrm{~S}_{4} \mathrm{Mo}_{2}$ : C. $39.07 ; \mathrm{H}, 2.81 ; \mathrm{N}, 9.76 ; \mathrm{S} .14 .90$. Found: C. 38.93; H. 2.87: N, 9.80; S, 15.34. UV-Vis (DMF) [ $\left.\lambda_{\max } \operatorname{nm}(\log \varepsilon)\right]$ : $406(3.90), 349(4.32) .319(4.35) .265(4.56) .256(4.21)$. $250(4.16), 244(4.11), 235(+.16) .226(4.05) .214(4.13)$. Siguificant IR bands $\left(\mathrm{cm}^{-1}\right): 3071$ (w). 1597 (m), 1587 (s). 1549 (s), 1485 (m). 1435 (w). 1275 (m), 1223 (w), 1028 (w). 981 (m). 923 (s), 894 (vs), 809 (m), 750 (m). ${ }^{1}$ H NMR (400 MHz. DMSO-d $): \delta 2.60$ (s. S- $\mathrm{CH}_{3} .6 \mathrm{H}$ ), 6.95 (d. ArH, $2 \mathrm{H} . J$ $=8.4 \mathrm{~Hz}, \mathbf{7} .06-7.10(\mathrm{~m} . \mathrm{ArH}, 2 \mathrm{H}), 7.54-7.59(\mathrm{ml}, \mathrm{ArH} .2 \mathrm{H})$. 7.78 (dd, $\mathrm{ArH}, 2 \mathrm{H}, J=7.8 \mathrm{~Hz}, 1.4 \mathrm{~Hz}$ ), 7.83 (dd, $-\mathrm{NCHCH}$ $4 \mathrm{H}, J=4.4 \mathrm{~Hz}, 1.6 \mathrm{~Hz}) .8 .73(\mathrm{dd},-\mathrm{NCHCH} \cdot .4 \mathrm{H}, J=4.4 \mathrm{~Hz}$. $1.6 \mathrm{~Hz}), 8.95$ (s. N=C. $.2 \mathrm{H}$ ).

$\left[\mathrm{Mo}_{2} \mathrm{O}_{4} \text { (sal-phtsc) }\right)_{2}\left(4,4^{\prime}\right.$-dpdo)] (4). The compound was prepared similarly by the method described above for the preparation of 1 . with use of $4,4^{\prime}$-dpdo and sal-phTscH: instead of 4, 4 -bpe and sal-mdtc $\mathrm{H}_{2}$. respectively. Yield: $60 \%$ $(0.200 \mathrm{~g})$. Anal. Calcd. for $\mathrm{C}_{38} \mathrm{H}_{30} \mathrm{~N}_{8} \mathrm{O}_{8} \mathrm{~S}_{2} \mathrm{Mo}_{2}: \mathrm{C}, 46.44 ; \mathrm{H}$. 3.08: N. 11.40; S. 6.53. Found: C. 46.10; H. 3.08; N, 10.59: S, 6.33. UV-Vis (DMF) [ $\hat{\lambda}_{\operatorname{lax}}$ Iun $(\log \varepsilon)$ ]: $436(3.71) .346$ (4.78). $268(4.54) .244$ (4.35). $21+$ (4.22). Significant IR bands $\left(\mathrm{cm}^{-1}\right): 3260$ (w). $3117(\mathrm{w}), 1597$ (s). 1559 (m), 1513 (vs), $1474(\mathrm{~m}), 1+38(\mathrm{vs}), 1318(\mathrm{~m}), 1272(\mathrm{~m}), 1212(\mathrm{vs})$. $1174(\mathrm{~m}), 924(\mathrm{~s}), 893(\mathrm{vs}), 860(\mathrm{~m}), 830(\mathrm{vs}), 747(\mathrm{vs}), 686$ (m). ${ }^{1} \mathrm{H}$ NMR $(400 \mathrm{MHz}$, DMSO-d 6$): \delta 6.90$ (d, ArH, $2 \mathrm{H} . \mathrm{J}$ $=8.4 \mathrm{~Hz}$ ), 6.98-7.05 (m. ArH, $4 \mathrm{H}), 7.28-7.33(\mathrm{~m}, \mathrm{ArH} .4 \mathrm{H})$. 7.47 (ddd. ArH. $2 \mathrm{H}, J=9.0 \mathrm{~Hz}, 6.8 \mathrm{~Hz} .1 .6 \mathrm{~Hz}$ ), 7.69 (dd. ArH. $2 \mathrm{H} . J=7.8 \mathrm{~Hz} .1 .8 \mathrm{~Hz}) .7 .73-7.76(\mathrm{~m} . \mathrm{ArH} .4 \mathrm{H}) .7 .87-$ 7.90 (m. - -NCHCH- $4 \mathrm{H}), 8.28-8.32(\mathrm{~m},-\mathrm{NCHCH}-4 \mathrm{H})$. 8.81 (s. $\mathrm{N}=\mathrm{CH}, 2 \mathrm{H}$ ). 9.68 (s. Ph- $\mathrm{NH} .2 \mathrm{H}$ ).

Crystal structure determination of 2. X-ray diffraction data of the single-crystal was collected at $293(2) \mathrm{K}$ on an ADSC Quantum 210 detector at Beamline 4A MXW of Pohang Light Source. The cry'stal evaluation and data collection were done using 0.76999 A-wavelength radiation with a detector-to-cry'stal distance of $6.0 \mathrm{~cm}$. Preliminary cell constants and an orientation matrix were determined from 36 sets of frames collected at scan intervals of $5^{\circ}$ with an exposure time of 1 second per frame. We got basic scale file from program HKL2000 (Otwinowski \& Minor. 1997). The reflections were successfully indexed by the automated indexing routine of the DENZO program. A total of 3.695 reflections were harvested by collecting 72 sets of frames with $5^{\circ}$ scans with an exposure time of 1 second per frame. This highly redundant data set was corrected for Lorentz and polarization effects. and a negligible correction for crystal decay was also applied. The space group R-3 was determin-
Table 1. Crystal datá and structure refinement for 2

\begin{tabular}{|c|c|}
\hline Empirical formula & $\mathrm{C} 31 \mathrm{H} 30 \mathrm{Mo} 2 \mathrm{~N} 6 \mathrm{O}$ S4 \\
\hline $\mathrm{Fw}$ & 918.76 \\
\hline Temp. (K) & $293(2)$ \\
\hline$\lambda(\AA)$ & 0.76999 \\
\hline Crystal system & Rhombohedral \\
\hline Space group & $\mathrm{R}-3$ \\
\hline $\mathrm{a}(\AA)$ & $14.5143(17)$ \\
\hline$a\left(^{\circ}\right)$ & $102.790(17)$ \\
\hline $\mathrm{V}\left(\AA^{3}\right)$ & $2787.8(6)$ \\
\hline 2 & 3 \\
\hline$D_{\text {cals: }}\left(\mathrm{Mg} / \mathrm{m}^{3}\right)$ & 1.699 \\
\hline$\mu\left(\mathrm{mm}^{-1}\right)$ & 0.957 \\
\hline$F(000)$ & 1440 \\
\hline Theta range for data collection & 1.63 to $30.40^{\circ}$ \\
\hline Index ranges & $1 \leq h \leq 19,-14 \leq k \leq 11,-14 \leq l \leq 11$ \\
\hline Reflections collected/unique & $3695 / 3695[\mathrm{R}(\mathrm{int})=0.0000]$ \\
\hline Completeness to theta $=30.40^{\circ}$ & $83.3 \%$ \\
\hline Absorption correction & None \\
\hline Refinement method & Full-matrix least-squares on $F^{2}$ \\
\hline Data / restraints / parameters & $3695 / 0 / 238$ \\
\hline Goodness-of-fit on F2 & 1.116 \\
\hline Final $R$ indices $[I>2$ sigma $(I)]$ & $R_{1}=0.1006, w R_{2}=0.2543$ \\
\hline $\mathrm{R}$ indices (all data) & $R_{1}=0.1006, w R_{2}=0.2543$ \\
\hline Largest diff. peak and hole & 3.089 and $-1.809 \mathrm{e} \AA^{-3}$ \\
\hline
\end{tabular}

ed by the program XPREP (ver. 6.12. Bruker-AXS). The structure was solved by direct method ${ }^{17}$ and refined on $\mathrm{F}^{2}$ by full-matrix least-squares procedures. ${ }^{18}$ All non-lydrogen atoms were refuned using anisotropic thermal parameters. Hydrogen atoms were included in the structure factor calculation at idealized positions by using riding model. but not refined. A summary of the experimental and crystallographic data for compound $\mathbf{2}$ is presented in Table 1.

\section{Results and Discussion}

The reaction of $\mathrm{MoO}_{2}(\mathrm{acac})_{2}$ with the schiff base ligands which are derived from salicylaldehyde and S-methyldithiocarbazate $^{19}$ or 4-phenylthiosemicarbazide with respective 4.4'-bpy, 4.4'-bpe. and 4.4'-dpdo in dichloromethane solution gave a dimeric dioxomolybdenum(VI) complexes 1-4. respectively. All complexes are air stable in the solid state and have poor solubilities in conmon organic solvents. but they are highly soluble in DMF and DMSO. The formulations are in accordance with the data of elemental analysis and physicochemical measurements. The oxidation state of Mo as expected from overall charge considerations for the complexes is +6 .

Spectral properties. The complexes show similar electronic spectra, suggesting that they have essentially similar structure. Since molybdenum(VI) ion has no d electron. absorption bands of pure $\mathrm{d}-\mathrm{d}$ origins are not expected to appear. The bands at $c a .414 \mathrm{~nm}(\log \varepsilon=c a .3 .86)$ for all complexes may possibly be assigned as charge transfer transition from oxygen orbital to a metal $d$-orbital. ${ }^{12,13} \mathrm{On}$ the other hand, the bands observed below $367 \mathrm{~nm}$ are due to intraligand transitions of sal-mdtc or sal-phtsc ligands. 
Infrared spectra for the complexes 1-4 show two intense absorption peaks at $c a .892$ and $c a .924 \mathrm{~cm}^{-1}$. These bands are assigned to the asymmetric and the symmetric stretching vibration of $c i s-\mathrm{MoO}_{2}$ group, respectively. by comparison with the spectra reported previously. ${ }^{3 i}$ For all complexes an intense vibration associated with the $\mathrm{C}=\mathrm{N}$ stretching fre-

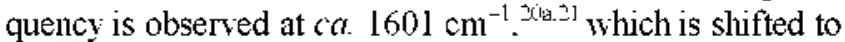
low frequency compared to $c a .1620 \mathrm{~cm}^{-1}$ of the free ligands. indicating that the azomethine nitrogen atom is coordinated to the molybdenum center. The complex + exhibits weak band at $3260 \mathrm{~cm}^{-1}$ due to the $\mathrm{NH}$ stretching vibration of salphtsc ligand. ${ }^{3 i}$ The ligands binding to $\mathrm{MoO}_{2}$ group are also supported from the results of ${ }^{1} \mathrm{H}-\mathrm{NMR}$ measurements. The ${ }^{1} \mathrm{H}$-NMR spectra for the complex 1 exhibits $\mathrm{N}=\mathrm{CH}$ proton resonance at $8.92 \mathrm{ppm}$. three different 4.4'-bpe proton resonances at three different positions $(8.57 \mathrm{ppm}$ for $\mathrm{NCHCH}$. $7.57 \mathrm{ppm}$ for $\mathrm{NCHCH}$. and $7.51 \mathrm{ppm}$ for $-\mathrm{NCH}=\mathrm{CHN}-$ ). aromatic proton bands at $6.92-7.74 \mathrm{ppm}$. and methyl proton signal at $2.56 \mathrm{ppm}$. respectively. ${ }^{8,13,14.4}$ The ratio of integrated intensities for the proton resonances of $\mathrm{N}=\mathrm{CH}(2)$ : $\mathrm{ArH}(6): \mathrm{ArH}(2)+-\mathrm{NCH}=\mathrm{CHN}-(2)+-\mathrm{NCHCH}(4):-\mathrm{NCHCH}-$ (4): $\mathrm{S}-\mathrm{CH}_{3}(6)$ shows $2.00: 6.06: 8.34: 3.83: 6.03$ consistent with the stoichiometric ratio of sal-mdtc: $4.4^{\prime}$-bpe $=2: 1$. ${ }^{1} \mathrm{H}$ NMR data of other complexes are given in the experimental section. The complexes of $\mathbf{3}$ and $\boldsymbol{4}$ show sumilar ${ }^{1} \mathrm{H}-\mathrm{NMR}$ spectra to the complex 1 . except disappearing the proton resonances for the $-\mathrm{NCH}=\mathrm{CHN}$ - of $4,4^{\prime}$-bpe and appearing the proton resonance for the phenyl anine of sal-phtsc ligand instead of disappearing the proton resonances for the methyl group of sal-mdtc ligand. respectively. The azomethine proton resonances ( 8.92 for $1,8.95$ for 3 and $8.81 \mathrm{ppm}$ for 4) in all conplexes are shifted to the down field compared to the resonances $\left(8.53 \mathrm{ppm}\right.$ for sal- $\mathrm{mdtcH}_{2}$ and $8.49 \mathrm{ppm}$ for sal-phts $\mathrm{CH}_{2}$ ) of the free ligands. Also, the signals for one $\mathrm{OH}$ proton resonance $\left(13.34 \mathrm{ppm}\right.$ for sal-mdtc $\mathrm{H}_{2}$ and $11.78 \mathrm{ppm}$ for sal-phts $\left.\mathrm{CH}_{\Sigma}\right)$ and one $\mathrm{NH}$ proton $(10.24 \mathrm{ppm}$ for salindtc $\mathrm{H}_{2}$ and $10.05 .9 .98 \mathrm{ppm}$ for sal-phts $\mathrm{CH}_{2}$ ) of the free schiff base ligands are found to disappear in the spectra of the complexes. These NMR data imply that the schiff base ligand coordinates to the $\mathrm{MoO}_{2}$ group in the thiolate form.

Structural description of compound 2. The molecular structure of complex 2 is shown in Figure 1. Selected bond lengths and angles are listed in Table 2 . The dinuclear complex crystallizes in the rhombohedral space group R-3 with a crystallographic center of inversion. the two equivalent halves of the molecule have a trons disposition with respect to the $\mathrm{Cl5}=\mathrm{Cl} 15 \mathrm{a}$ at the center. The molybdenum centers have a distorted octahedral coordination environment that consists of an sal-mdtc $\hat{i}^{-}$, two terminal oxygen atoms. and one nitrogen atom of one-half of the 4.4'-bpe group. Two molybdenum atoms (Mo-Mo distance $=14.189 \AA$ ) are linked by two bridge nitrogen atoms of $4.4^{\prime}$-bpe. The tridentate schiff base ligand. sal-mdtc ${ }^{2-}$ is bonded to the $c i s-\left[\mathrm{Mo}(\mathrm{VD}) \mathrm{O}_{2}\right]^{3+}$ core on a meridional plane through the phenolate- $\mathrm{O}$. the imine- $\mathrm{N}$, and the deprotonated thiolate-S atoms forming one five- and one six-membered chelate ring. In general the coordinaton environment around molybdenum centers

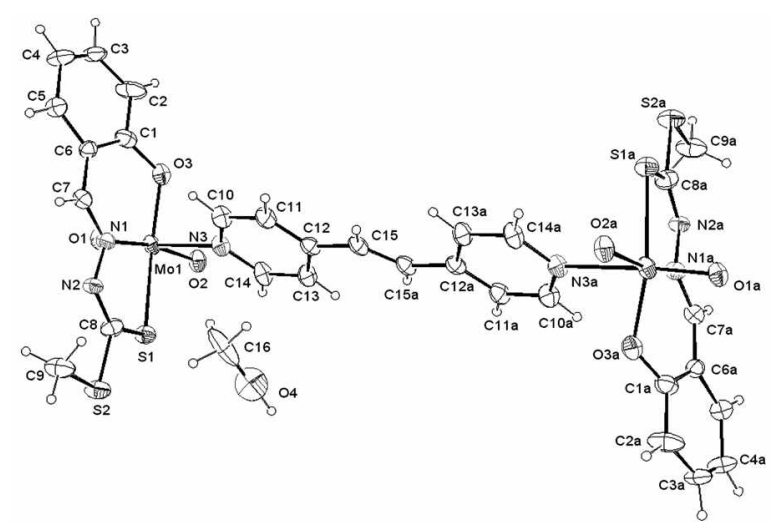

Figure 1. OrtepIII ${ }^{25}$ drawing of 2. Displacement ellipsoids are drawn at $30 \%$ probability level. Symmetry transformations used to generate equivalent atoms: $\mathrm{Aa}-\mathrm{x}+2,-\mathrm{y}+1,-\mathrm{z}+1$.

resemble those of the mononuclear cis-dioxomolybdenum (VI) complexes with tridentate schiff base ligand have been prepared previously in our laboratory. ${ }^{12}$

The average $\mathrm{Mo}_{\mathrm{O}} \mathrm{O}$ bond length $(1.711(7) \AA)$ and the $\mathrm{O}=\mathrm{Mo}=\mathrm{O}$ bond angle $\left(106.0(3)^{\circ}\right)$ are typical for $c i s-\mathrm{MoO}_{2}$ group. ${ }^{2-.+1}$ The Mo-O3 bond length $[1.921(8) \AA]$ is relatively longer than the values of $\mathrm{Mo}=\mathrm{O}_{\text {titennnall }}$ due to the bond order. The bond lengths for Mo-Sl and Mo-Nl are also similar to those reported for other complexes ${ }^{12}$ (Table 2). The cis- and trans- L-Mo-L angles are in the range of $75.7(2)-106.4(3)^{\circ}$ and $151.1(2)-169.6(3)^{\circ}$, respectively. To a large extent these distortions stem from the incorporation of Mo into a five-membered ring. The bond lengths. N1-C7 $(1.285(13) \AA)$ and $\mathrm{N} 2-\mathrm{C} 8[1.290(12) \AA]$ indicate that these are double bonds. respectively (normal single bond is 1.364 A). ${ }^{\text {. }}$ "The metric parameters for the five- and six-membered ring which are formed upon coordination of ligand are unexceptional and compare closely to those in related molecules. ${ }^{1 \text { bb }}$ The metric parameters for $4.4^{\prime}$-bpe are as followings: 1.34(2)-1.46(2) and $c a$. 1.35(1) A for C-C and C-N bond lengths. and $116.7(9)-124.1(11)$ and $117.6(9)^{\circ}$ for $\mathrm{C}-\mathrm{C}$ $\mathrm{C}$ and $\mathrm{C}-\mathrm{N}-\mathrm{C}$ angles. respectively.

Table 2. Selected bond lengths $(A)$ and angles $\left({ }^{\circ}\right)$ for complex 2

\begin{tabular}{llll}
\hline $\mathrm{Mo}(1)-\mathrm{O}(1)$ & $1.707(7)$ & $\mathrm{Mo}(1)-\mathrm{O}(2)$ & $1.714(7)$ \\
$\mathrm{Mo}(1)-\mathrm{O}(3)$ & $1.921(8)$ & $\mathrm{Mo}(1)-\mathrm{N}(1)$ & $2.267(8)$ \\
$\mathrm{Mo}(1)-\mathrm{N}(3)$ & $2.426(8)$ & $\mathrm{Mo}(1)-\mathrm{S}(1)$ & $2.471(3)$ \\
$\mathrm{S}(1)-\mathrm{C}(8)$ & $1.719(11)$ & $\mathrm{S}(2)-\mathrm{C}(8)$ & $1.791(11)$ \\
$\mathrm{N}(2)-\mathrm{C}(8)$ & $1.290(12)$ & $\mathrm{N}(1)-\mathrm{N}(2)$ & $1.422(10)$ \\
$\mathrm{N}(1)-\mathrm{C}(7)$ & $1.285(13)$ & $\mathrm{C}(6)-\mathrm{C}(7)$ & $1.410(13)$ \\
$\mathrm{C}(1)-\mathrm{C}(6)$ & $1.396(14)$ & $\mathrm{O}(3)-\mathrm{C}(1)$ & $1.371(14)$ \\
$\mathrm{N}(3)-\mathrm{C}(10)$ & $1.353(13)$ & & \\
O(2)-Mo(1)-O(1) & $106.0(3)$ & $\mathrm{O}(2)-\mathrm{Mo}(1)-\mathrm{O}(3)$ & $106.4(3)$ \\
O(1)-Mo(1)-O(3) & $98.2(3)$ & $\mathrm{O}(2)-\mathrm{Mo}(1)-\mathrm{N}(1)$ & $158.5(3)$ \\
$\mathrm{O}(1)-\mathrm{Mo}(1)-\mathrm{N}(1)$ & $92.1(3)$ & $\mathrm{O}(3)-\mathrm{Mo}(1)-\mathrm{N}(1)$ & $81.8(3)$ \\
O(2)-Mo(1)-N(3) & $84.2(3)$ & $\mathrm{O}(1)-\mathrm{Mo}(1)-\mathrm{N}(3)$ & $169.6(3)$ \\
(3)-Mo(1)-N(3) & $76.9(3)$ & $\mathrm{N}(1)-\mathrm{Mo}(1)-\mathrm{N}(3)$ & $78.2(3)$ \\
O(2)-Mo(1)-S(1) & $89.4(3)$ & $\mathrm{O}(1)-\mathrm{Mo}(1)-\mathrm{S}(1)$ & $100.5(2)$ \\
O(3)-Mo(1)-S(1) & $151.1(2)$ & $\mathrm{N}(1)-\mathrm{Mo}(1)-\mathrm{S}(1)$ & $75.7(2)$ \\
$\mathrm{N}(3)-\mathrm{Mo}(1)-\mathrm{S}(1)$ & $80.9(2)$ & $\mathrm{S}(1)-\mathrm{C}(8)-\mathrm{S}(2)$ & $113.5(5)$ \\
\hline
\end{tabular}




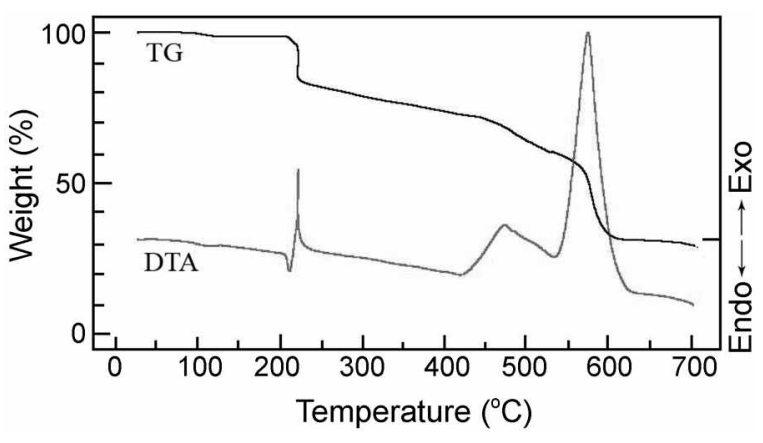

Figure 2. TG curve of complex 1.

Thermal properties. The thermogravimetric analyses (TGA) of complexes were conducted in the temperature range of $30-700^{\circ} \mathrm{C}$ with a $10^{\circ} \mathrm{C} / \mathrm{min}$ temperature interval. Their thermal decomposition behaviors are very similar to each other. No obvious decompositions are observed below $200^{\circ} \mathrm{C}$. Above this temperature the TG curve exhibits two steps of weight losses. The TG curve for the representative complex 1 is shown in Figure 2.

Complex 1 undergoes a rapid weight loss of $16.18 \%$ in the temperature range of $200-242{ }^{\circ} \mathrm{C}$. corresponding to the release of $4,4^{\prime}$-bpe ligand (calculated: $17.48 \%$ ). The second gradual weight loss of $50.81 \%$ in the range of $242-613{ }^{\circ} \mathrm{C}$ due to the loss of two sal-nddtc ligands in the formula unit (calculated: $50.59 \%$ ) is observed. These weight losses were accompanied by exothermic effect on the DTA curve with maximun at 220,472 , and $593^{\circ} \mathrm{C}$, respectively. For complex 3 , the TGA curve shows a rapid and significant weight loss of $30.91 \%$ in the temperature ranges of $210.253^{\circ} \mathrm{C}$ and the gradual weight loss of $36.27 \%$ between 253 and $543^{\circ} \mathrm{C}$. The total weight loss of $67.18 \%$ may be the conconitant release of the 4,4'-bpy and sal-mdtc ligands, with a calculated value of $70.27 \%$. The complex + shows the decompositions of $4,4^{\prime}$-dpdo and sal-phtsc ligand in the temperature range of $220-242{ }^{\circ} \mathrm{C}$ with weight loss of $20.22 \%$ (calculated $19.15 \%$ ) and of $242-568{ }^{\circ} \mathrm{C}$ with weight loss of $51.99 \%$ (calculated $54.81 \%$ ), respectively

\section{Conclusions}

Four new dimeric dioxomolybdenun(VI) complexes. $\left[\mathrm{Mo}_{2} \mathrm{O}_{4} \text { (schiff base) }\right)_{2}$ (diamine)] type. with the ONS-donnor schiff base and dianine ligands or its derivatives have been synthesized and characterized. In all complexes. the structure consists of two [ $\mathrm{MoO}_{2}$ (schiff base)] moieties bridged by two $\mathrm{N}$ atoms from diamine ligand. To our knowledge, these structures are not common. It is anticipated that the various structure of nultinuclear molybdenum complexes may be synthesized under the different reaction conditions. such as stoichiometry. solvent effect, and etc.

Supporting information available. Crystallographic data for the structure reported here have been deposited with the Cambridge Crystallographic Data Center (Deposition No. CCDC-689421 (2)). The data can be obtained free of charge via www.cedc. cam.ac.uk/conts/retrieving.html (or from the
CCDC, 12 Union Road, Cambridge CB2 IEZ, UK; fax: +44 1223336033 ; e-mail: depositajcdc.cam ac.uk).

\section{References}

1. (a) Stiefel. E. I. Science 1996. 272, 1599. (b) Wang. G.: Chen, G: Luck. R. L.: Wang, Z.: Mu. Z.: Evans, D. G.; Duan, X. Inorg. Chint Acta 2004. 357.3223 .

2. (a) Sellman, D. Angew: Chem, Int. Ed. 1993. 32, 64, (b) Kim, J; Wood. D.: Ress. D. C. Biochentism 1993. 32.7104. (c) Schultz. B. E:; Gheller. S. F.: Muetterties, M. C.: Scott, M. J.: Holm, R. H. J. Ant Chem. Soc. 1993. 115. 2714.

3. (a) Stiefel. E. I. Prog loog. Chem 1977, 22. 1. (b) Rao. S. N.; Kathale. N.: Rao. N. N.: Mutrshi. K. N. Inorg. Chim. Acta 2007. 360.4010

4. Agustin. D.: Darana. T. C.: Polia. R. Acta Crnst. 2008. C6t. ml01

5. Okabe. N.: Isomoto. N.; Odoko, M. Acta Ciyst 2002. E58, ml

6. Young. C. T.: McCleverty. J. A.: Mayer. T. T. Comprehensine Coordination Chemistry II: Elsevier: Amsterdam. 2003; vol. 4, pp 415-527 and refs. therein.

7. Tunney. J. M; McMaster. J.: Gamer. C. D: MoCleverty; J. A: Mayer. I. I. Comprehensine Coondination Chemistry II: Ëlsevier: Amsterdam. 2003; vol. 8, pp 459.477 and refs. therein.

8. (a) Tang. Y. J.: Mo. S. J.: Koo. B. K. Bull. Korem Chem. Soc. 1998. 19. 587. (b) Cai, L. Z.: Song, L. J.: Zeng, H. Y.; Dong, Z. C:

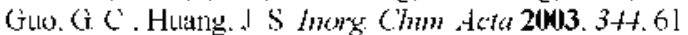

9. (a) Cindric. M.: Vrdoljak. V; Strukan. N: Kamenar, B Polvhedron 2005, 24. 369. (b) Bustos. C.: Burckhardt. O.: Schrebler, R.: Carrillo. D.: Arif, A. M.; Cowley. A. H.: Nunn. C. M. Inorg Chem 1990, 29. 3996. (c) Chen, S. M. Lu, C. Z.: Yu. Y. Q: Zhang. Q. Z: He. X. Acta Chst 2004. C60. m437.

10. Rana, A.: Dinda, R.: Ghosh. S.; Blake. A. Polyhedron 2003, 22,3075.

11. Rana. A.: Dinda. R.: Sengupta. P.: Ghosh. S.: Falvello. L. R. Polvhedron 2002, 21. 1023.

12. (a) Kim. H. J.: Koo. B. K. Bull. Korean Chem. Soc. 1994. 15. 766. (b) Kim. D. W. Koo, B. K. Bull. Konan Chem. Soc. 2004. 25,1071

13. Mo. S. T.: Koo. B. K. Bull. Korean Chem. Soc. 1999. 20. 1105.

14. Glowiak, T.; Jerzykiewicz, L.: Sobezak. J. M: Ziolkowshi, J. J. Inorg. Chim .Acta 2003. 356.387 and refs therein.

15. (a) Zapf. P. J;: Hausehalter, R. C.; Zubieta. J. Chem. Conmun. 1997. 321. (b) Dinda. R.: Ghosh. S.: Falvello. L. R.: Tomas. M: Mak. T. C. W. Polyhedron 2006, 25, 2375.

16. (a) Jang. Y. J.: Lee. U.: Koo. B. K. Bull. Korean Chem. Soc. 2005. 26,72. (b) Das. M. Livingstone, S. E. Inorg. Chim Acta 1976. 19,5.

17. Sheldrick. G. M. Acta Crnot 1990. $4+6.467$.

18. Sheldrick, G. M. SHELiS97-2 and SHEL1797-2: University of Gottingen: Gottingen. Gemany. 1997

19. Ali. M. A.: Livingstone. S. E.: Philips. D. J. Inorg. Chim. Acta 1973. 7,179.

20. (a) Dina. R.: Ghosh. S.: Falvello. L. R.: Tomas. M: Mak, T. C. W. Polyedron 2006. 25. 2375. (b) Glowiak. T.: Telzykiewicz. L: Sobezak, J. M.: Ziolkowski, J. J. Inorg. Chim Acta 2003. 356. 387. (c) Nica. S.: Kudolph. M : Gorls. H: Plass. W. hong Chim. Acta 2007. 360.1743.

21. (a) Rana, A.: Dina, R; Sengupta, P.: Falvello, L. R: Ghosh. S Pohyedron 2012. 21. 1023. (b) Dina. R.: Sengupta. P.: Ghosh. S.: Figge. H. M.; Sheldrick. W. S. J. Chem. Soc. Dalton Trans. 2002. 4434. (c) Dina. R.: Sentoupta. P.: Ghosh. S.: Sheldrick. W. S. Eur. J. horg. Chem 2003, 363. (d) Dina. R.: Sengupta. P. Mak, T. C. W: Ghosh. S. horg. Chem. 2002. H. 1684.

22. (a) Dutta, S. K.: MeConville, D. B.: Youngs. W. J.: Chaudhury, M Inorg. Chem. 1997.36.2517. (b) Zhou. Z. H.: Deng. Y. F.: Cao. Z. X; Zhang, R. H; Chow, Y. L. Inorg. Chem. 2005, H4. 6912.

23. (a) Berg. J. M.: Holm. R. H. J. An Chent Soc. 1984. 106. 3035. (b) Lyashento, G.: Jancik. V: Pal, A,; Regine, H.-I.; Nadia, C. M.Z. Dalton Trams 2006. 1294.

24. Limatainen, J.: Lehtonen, A.: Sillanpaa. R. Polyhedron 2000. 19. 1133.

25. Farrugia, L. J. J. Appl. Cysst 1997. 30, 565. 